\title{
Mitral valve replacement for rheumatic heart disease in Southern Africa
}

\author{
P Zilla,, J Koshy, J Brink, P Human \\ From 23rd World Congress of the World Society of Cardio-Thoracic Surgeons \\ Split, Croatia. 12-15 September 2013
}

\section{Background}

Threshold countries like South Africa provide cardiac surgery to a largely indigent population with rheumatic heart disease. Although repairs are a preferred treatment modality many rheumatic mitral valves can only be replaced. In view of significantly improved primary health care and broad access of the indigent population to communication technology we revisited the efficacy of mitral valve replacement (MVR) at the interface of the developing and developed world.

\section{Methods}

A cohort of 280 patients (mean age $40.7 \pm 13.7 \mathrm{y} /$ range $12-80 \mathrm{y} /$ median $41 \mathrm{y} ; 76.4 \%$ female) with rheumatic heart disease (21\% MR; 11\% MS; 68\% mixed) undergoing mitral valve replacement (MVR) (88.2\% mechanical versus 11.8\% tissue valves) was analyzed.

\section{Results}

Follow-up for the entire cohort was $94 \%$ complete (median follow-up period 3.5 years). Actuarial 5-year freedom from valve related reoperation/death was $81.5 \pm 2.9 \% / 96.7$ $\pm 1.3 \%$ in the mechanical and $81.8 \pm 6.7 \% / 100 \pm 0 \%$ in the tissue valve group $(\mathrm{p}=0.562 / 0.970)$. There was no significant difference in freedom from death or reoperation irrespective of whether INR tests were performed or not. In the mechanical group, partition modeling demonstrated a significant difference with respect to freedom from death $(95.3 \pm 3.2 \%$ versus $82.9 \pm 4.1 \% \% ; \mathrm{p}=0.013)$ but not with respect to freedom from reoperation $(98.2 \pm 1.8 \%$ versus $96.2 \pm 3.8 \% ; \mathrm{p}=0.329$ ) between patients divided by an INR cut point of $34 \%$ of tests falling within the therapeutic range. Compared to the tissue valve group, the mechanical group with poor INR control was statistically equivalent with respect to survival and reoperation rate.

* Correspondence: Peter.Zilla@uct.ac.za

University of Cape Town, Cape Town, South Africa

\section{Conclusion}

Overall circumstances for patients with rheumatic heart disease needing mitral valve replacement in a developing country have become conducive for the use of mechanical prostheses. Yet, the remaining inferior outcome in patients with suboptimal INR control highlights the need for alternative anticoagulation agents that require less stringent dosing.

Published: 11 September 2013

doi:10.1186/1749-8090-8-S1-0294

Cite this article as: Zilla et al.: Mitral valve replacement for rheumatic heart disease in Southern Africa. Journal of Cardiothoracic Surgery 2013 8(Suppl 1):0294.
Submit your next manuscript to BioMed Central and take full advantage of:

- Convenient online submission

- Thorough peer review

- No space constraints or color figure charges

- Immediate publication on acceptance

- Inclusion in PubMed, CAS, Scopus and Google Scholar

- Research which is freely available for redistribution
( Biomed Central
C Biomed Central

(c) 2013 Zilla et al; licensee BioMed Central Ltd. This is an Open Access article distributed under the terms of the Creative Commons Attribution License (http://creativecommons.org/licenses/by/2.0), which permits unrestricted use, distribution, and reproduction in any medium, provided the original work is properly cited. 